\title{
MANAJEMEN KEUANGAN KELUARGA
}

\author{
Leny Nofianti \\ Angrieta Denziana
}

\author{
Fak. Ekonomi \& Ilmu Sosial UIN Suska Riau \\ lenynofianti@yahoo.com
}

\begin{abstract}
Abstrak: The housewife generally represents as a menager in managing family finance. There are several key concepts of family finance management which is important to know in order to manage the family finance professionally. They are balance and loss/profit and also the management of cashflow. With the existence of a good understanding about family financial report, supported by good planning, division of duty with couple and effort of interrogating the extra of expenditure, hence the domestic can through the family finance problem with the correct solution. The most important thing is openness each other and also experiences the family life responsibility with.
\end{abstract}

Kata Kunci: manajemen, keuangan, keluarga

\section{PENDAHULUAN}

Masalah utama sebuah keluarga yang selalu ada biasanya seputar keuangan. Bisa karena kekurangan uang, kelebihan uang, atau karena bingung bagaimana mengatur uang bagi orang yang penghasilannya paspasan, sedangkan kebutuhan selalu melebihi pemasukan.

Namun muara dari itu semua, kata kuncinya adalah bagaimana mengatur keuangan keluarga atau pribadi dengan cerdas, cermat dan sebaik-baiknya. Karena masalah mengatur keuangan tidak memandang 
orang miskin, menengah atau kaya. Karena siapa pun bisa mengatur keuangan keluarganya. Jika telah bisa mengelola keuangan keluarganya maka bisa dikatakan 50\% mereka sudah sukses dan berhasil dalam hal finansialnya.

Penelitian yang dilakukan oleh Lisma Dyawati Fuaida $(2004)^{1}$ mengenai manajemen keuangan keluarga miskin, studi kasus mitra program masyarakat mandiri, dompet dhuafa Republika, ditemukan bahwa adanya perbedaan pendapatan, tingkat kemampuan dan kemandirian keluarga dalam hal mengelola keuangan di setiap keluarga mitra program masyarakat mandiri, dompet dhuafa Republika di Bogor, Tangerang dan Bekasi, baik dari segi input, troughput dan output.

Tulisan ini mencoba membahas lebih dalam mengenai teknik pengelolaan keuangan rumah tangga yang baik dilihat dari sisi manajemen keuangan, dengan harapan dapat memberikan masukan untuk memecahkan masalah keuangan yang dihadapi dalam keluarga.

\section{PEMBAHASAN}

Sebelum membahas lebih lanjut tentang manajemen keuangan keluarga, ada baiknya dibahas terlebih dahulu mengenai manajemen, manajemen keuangan, dan manajemen keuangan keluarga.

\section{Manajemen}

Manusia, finansial, modal fisik dan teknologi adalah jenis-jenis sumber daya organisasi unit bisnis yang perlu dikelola dengan optimal untuk mencapai tujuan organisasi. Manajemen pada dasarnya merupakan proses pemanfaatan sejumlah sumber daya organisasi untuk mencapai tujuan tertentu melalui proses perencanaan, pengorganisasian, pengarahan dan pengendalian.

Kata manajemen berasal dari bahasa Italia (1561) maneggiare yang berarti "mengendalikan," terutamanya "mengendalikan kuda" yang berasal dari bahasa Latin manus yang berati "tangan". Kata ini mendapat pengaruh dari bahasa Perancis manège yang berarti "kepemilikan kuda" (yang berasal dari Bahasa Inggris yang berarti seni mengendalikan kuda), dimana istilah Inggris ini juga berasal dari bahasa Italia. Bahasa Prancis lalu mengadopsi kata ini dari bahasa Inggris menjadi ménagement, yang memiliki arti seni melaksanakan dan mengatur. ${ }^{2}$

Dalam mengartikan dan mendefenisikan manajemen ada berbagai macam pendapat. Ada yang mengartikan dengan ketatalaksanaan, manajemen, manajemen pengurusan dan lain sebagainya. Bila dilihat dari literatur-literatur yang ada, pengertian manajemen dapat dilihat dari tiga pengertian, yaitu $u^{3}$ manajemen sebagai suatu proses, manajemen sebagai suatu kolektivitas manusia, manajemen sebagai ilmu (science) atau sebagai seni (art). 
Manajemen sebagai suatu proses, melihat bagaimana cara orang untuk mencapai suatu tujuan yang telah ditetapkan terlebih dahulu. Manajemen suatu kolektivitas yaitu merupakan suatu kumpulan dari orang-orang yang bekerjasama untuk mencapai suatu tujuan bersama. Kolektivitas atau kumpulan orang-orang inilah yang disebut dengan manajemen, sedang orang yang bertanggung jawab terhadap terlaksananya suatu tujuan atau berjalannya aktivitas manajemen disebut manajer. Manajemen sebagai suatu ilmu dan seni, melihat bagaimana aktivitas manajemen dihubungkan dengan prinsip-prinsip dari manajemen.

Pengertian Manajemen menurut Mary Parker Foller (1997) ${ }^{4}$ dalam sutisna (2008), Management is the art of getting things done through people, managemen adalah seni menyelesaikan sesuatu melalui orang lain. "Menyelesaikan sesuatu" yang dimaksud disini adalah segala sesuatu yang perlu dilakukan dalam rangka mencapai tujuan tertentu.

Menurut Nickles, McHingh, dan McHugh (1997) dalam Sutisna $(2008)^{5}$ management is the process used the accompalish organizational golas through planning, organizing, directing, and controlling people and other organizational resources. Managemen adalah sebuah proses yang dilakukan untuk mewujudkan tujuan organisasi melalui rangkaian kegiatan berupa perencanaan, pengorganisasian, pengarahan, dan pengendalian orangorang serta sumber daya organisasi lainnya.

Berdasarkan pengertian diatas, dapat disimpulkan bahwa manajemen pada dasarnya merupakan seni atau proses dalam menyelesaikan sesuatu yang terkait dengan pencapaian tujuan. Dalam pencapaian tujuan tersebut terdapat tiga faktor, yaitu: 1) Adanya penggunaan sumber daya organisasi, baik sumber daya manusia, alam, ataupun faktor produksi lainnya, 2) Adanya proses bertahan dari mulai perencanaan, pengorganisasian, pengarahan, dan pengendalian, 3) Adanya seni dalam menyelesaikan pekerjaan. Dan hal ini merupakan bakat dan keterampilan seseorang.

\section{Manajemen Keuangan}

Manajemen Keuangan merupakan suatu kegiatan perencanaan, penganggaran, pemeriksaan, pengelolaan, pengendalian, pencarian dan penyimpanan dana yang dimiliki oleh organisasi atau perusahaan. ${ }^{6}$

Maksud dari masing-masing fungsi manajemen keuangan tersebut adalah : 1) Perencanaan Keuangan, yaitu membuat rencana pemasukan dan pengeluaraan serta kegiatan-kegiatan lainnya untuk periode tertentu. 2) Penganggaran Keuangan, yaitu tindak lanjut dari perencanaan keuangan dengan membuat detail pengeluaran dan pemasukan, 3) Pengelolaan Keuangan, yaitu menggunakan dana perusahaan untuk memaksimalkan dana yang ada dengan berbagai cara, 4) Pencarian Keuangan, yaitu mencari dan mengeksploitasi sumber dana yang ada 
untuk operasional kegiatan perusahaan, 5) Penyimpanan Keuangan, yaitu mengumpulkan dana perusahaan serta menyimpan dana tersebut dengan aman, 6) Pengendalian Keuangan, yaitu melakukan evaluasi serta perbaikan atas keuangan dan sistem keuangan pada perusahaan, 7) Pemeriksaan Keuangan, yaitu melakukan audit internal atas keuangan perusahaan yang ada agar tidak terjadi penyimpangan.

Keputusan dalam manajemen keuangan bisa berupa: a) Keputusan investasi, b) Keputusan pembelanjaan dan pembiayaan, c) Keputusan manajemen aktiva

Tanggung jawab seorang manajer keuangan dapat berupa peramalan dan perencanaan keuangan, keputusan besar dalam investasi dan pembiayaan, pengkoordinasian dan pengendalian serta interaksi dengan pasar modal.

Dapat disimpulkan, manajemen keuangan merupakan salah satu bidang manajemen fungsional dalam suatu perusahaan, yang mempelajari tentang penggunaan dana, memperoleh dana dan pembagian hasil operasi perusahaan. Dalam hal ini perusahaan diidentikkan dengan keluarga.

Manajemen keuangan dapat didefinisikan dari tugas dan tanggung jawab manajer keuangan. Meskipun tugas dan tanggung jawabnya berlainan di setiap perusahaan, tugas pokok manajemen keuangan antara lain meliputi : keputusan tentang investasi, pembiayaan kegiatan usaha dan pembagian dividen suatu perusahaan (Weston dan Copeland, 1992: 2, dalam My family accounting). ${ }^{7}$

\section{Manajemen Keuangan Keluarga}

Dalam mengelola manajemen keluarga, yang bertindak sebagai manajer biasanya adalah ibu rumah tangga. Agar dapat mengelola keuangan keluarga secara professional, keluarga perlu mengetahui beberapa konsep utama tentang manajemen keuangan keluarga.

Ada dua konsep utama tentang manajemen keuangan keluarga yang wajib diketahui oleh keluarga yaitu tentang Neraca dan Rugi/Laba serta Manajemen Cashflow/Arus Kas. Untuk lebih jelasnya dapat dilihat pada gambar di bawah ini: 


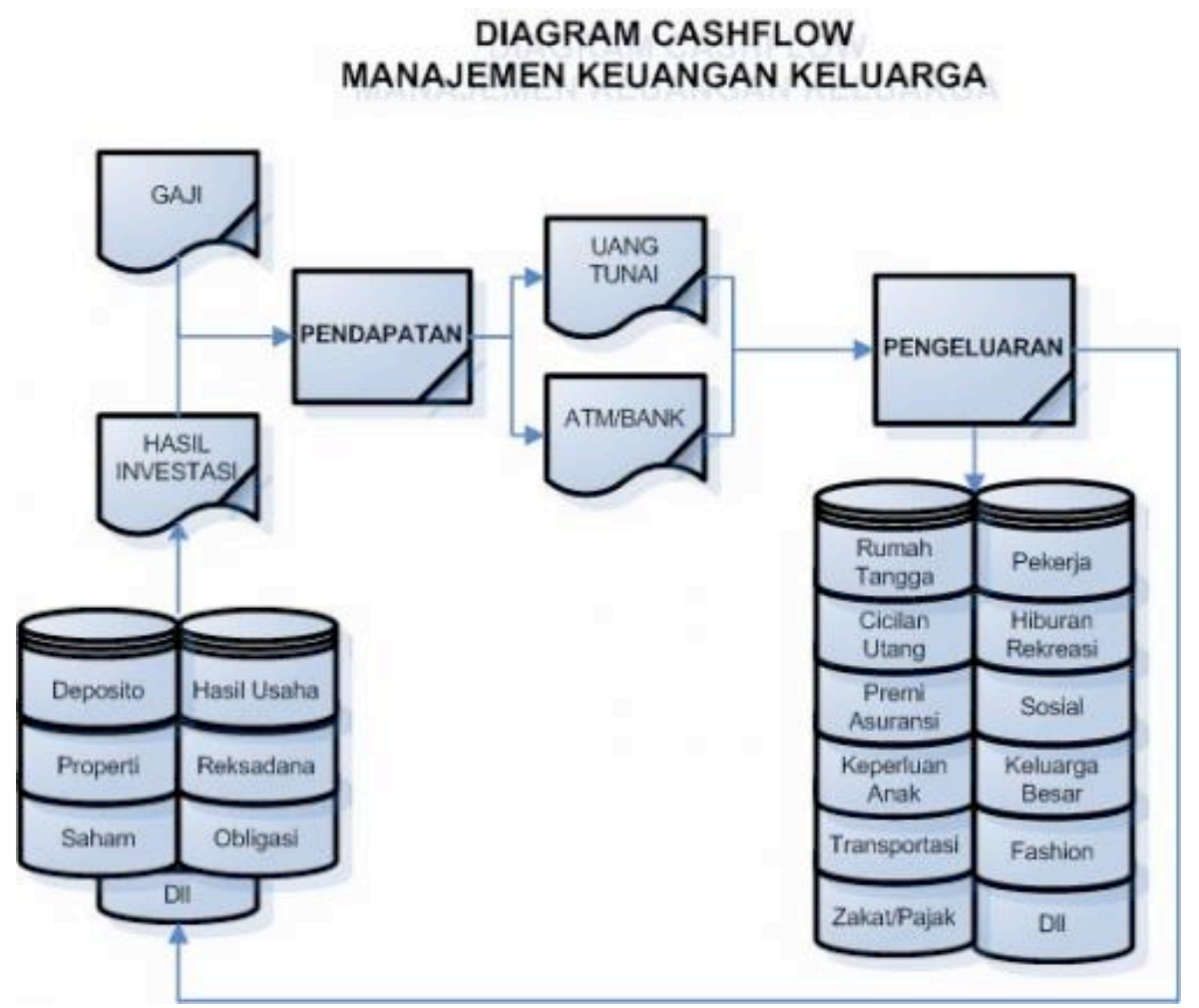

Sumber: My Family Accounting8

\section{Memahami Manajemen Cashflow}

Cashflow atau arus kas adalah aliran uang yang mengalir mulai dari kita mendapatkan uang tersebut, menyimpannya, mengembangkannya, dan mengeluarkannya dengan secara teratur, bijak dan disiplin.Pengetahuan akan cashflow wajib diketahui agar keuangan keluarga kita tidak akan kacau balau dan terpantau. Ada sebuah ungkapan yang cukup menarik "tidak peduli keuangan Anda sedang defisit, yang penting Anda tahu kemana mengalirnya uang tersebut."

Penjelasan mengenai diagram cashflow sebagai berikut :

Pertama, Pendapatan. Pendapatan (income) adalah kegiatan yang bertujuan memasukkan uang/harta. Biasanya pendapatan dapat diperoleh dari dua aktivitas, yaitu Gaji dan Investasi. Gaji diperoleh dari status sebagai pegawai/karyawan/professional/konsultan. Dalam sebuah keluarga gaji ini bisa diperoleh oleh suami dan istri yang bekerja.

Hasil Investasi diperoleh dari aktivitas kita dalam mengembangkan uang/harta dalam berbagai cara. Ada beberapa cara yang dapat dilakukan berinvestasi yaitu Deposito, Properti, Saham, Hasil Usaha, Reksadana, Obligasi, dan lain-lain. Seluruh pendapatan kita tersebut biasanya disimpan dalam bentuk tunai atau di bank/ ATM.

Kedua, Pengeluaran. Pengeluaran berarti seluruh kegiatan yang mengakibatkan uang berkurang. Dari diagram bisa dilihat banyak sekali 
kebutuhan akan pengeluaran keluarga. Sehingga bila tidak diatur dengan baik maka bakal membuat keuangan keluarga menjadi kacau dan bila sudah kronis dapat menuju ke jurang kebangkrutan. Secara umum sebuah keluarga memiliki beberapa pengeluaran seperti Pengeluaran Rumah Tangga, Cicilan Utang, Premi Asuransi, Pembantu Rumah Tangga, Keperluan Anak, Transportasi, Zakat/Pajak, Hiburan/Rekreasi, Kegiatan Sosial, Fashion, dan sebagainya.

Bila diperhatikan, kesalahan yang sering dilakukan oleh kebanyakan keluarga adalah hanya berkutat pada pendapatan yang berasal dari gaji yang terus-menerus dikuras untuk menutupi pengeluarannya. Sangat sedikit dari keluarga kita yang mulai melakukan aktivitas-aktivitas investasi sebagai sumber pendapatan keluarganya. Padahal apabila rajin melakukan investasi, maka hasil dari investasi tersebut sebenarnya sudah dapat menutupi segala macam pengeluaran kita, bahkan bisa jauh lebih besar dari gaji yang diterima selama ini. Bila keluarga masih bergantung sepenuhnya pada aliran pemasukan dari gaji setiap bulan, maka sudah waktunya untuk sedikit demi sedikit menyisihkan uang agar bisa membuat aliran pemasukan baru yang berasal dari investasi.

Ketiga, Catatan atas Laporan Kekayaan dan Laba Rugi. Apabila ada orang yang bertanya, berapa kekayaan bersih Anda saat ini? berapa persen pertumbuhan kekayaan Anda dibanding tahun kemarin? Berapa laba/surplus pendapatan Anda bulan ini? Berapa persen pertambahan/penurunan laba/surplus pendapatan Anda bulan ini dibanding bulan yang sama pada tahun sebelumnya?, Hampir banyak yang tidak siap memberikan jawaban seketika itu juga. Hal ini dikarenakan kebanyakan dari keluarga tidak memiliki catatan/laporan kekayaan dan laba rugi keluarga kita setiap periode/bulan. Berbeda halnya di dunia bisnis, setiap periode atau bulan perusahaan memiliki catatan atas laporan kekayaan dan laba rugi perusahaannya. Karena bila perusahaan tidak memiliki laporan tersebut, tentu akan menyulitkan pada pemimpin perusahaan untuk mengetahui posisi finansial perusahaannya, sehingga sangat tidak mungkin dapat mengambil keputusan-keputusan bisnis perusahaan.

Apabila diamati, sebenarnya dalam mengelola keuangan keluarga, prinsip operasional secara umum hampir selalu sama dengan pengelolaan keuangan di perusahaan, misalnya aktivitas-aktivitas pencatatan uang kas yang masuk dan keluar, mengumpulkan bukti-bukti transaksi, membuat anggaran pendapatan dan belanja, mengelola hutang/piutang, laporan kekayaan atau neraca dan laba rugi di akhir periode. 


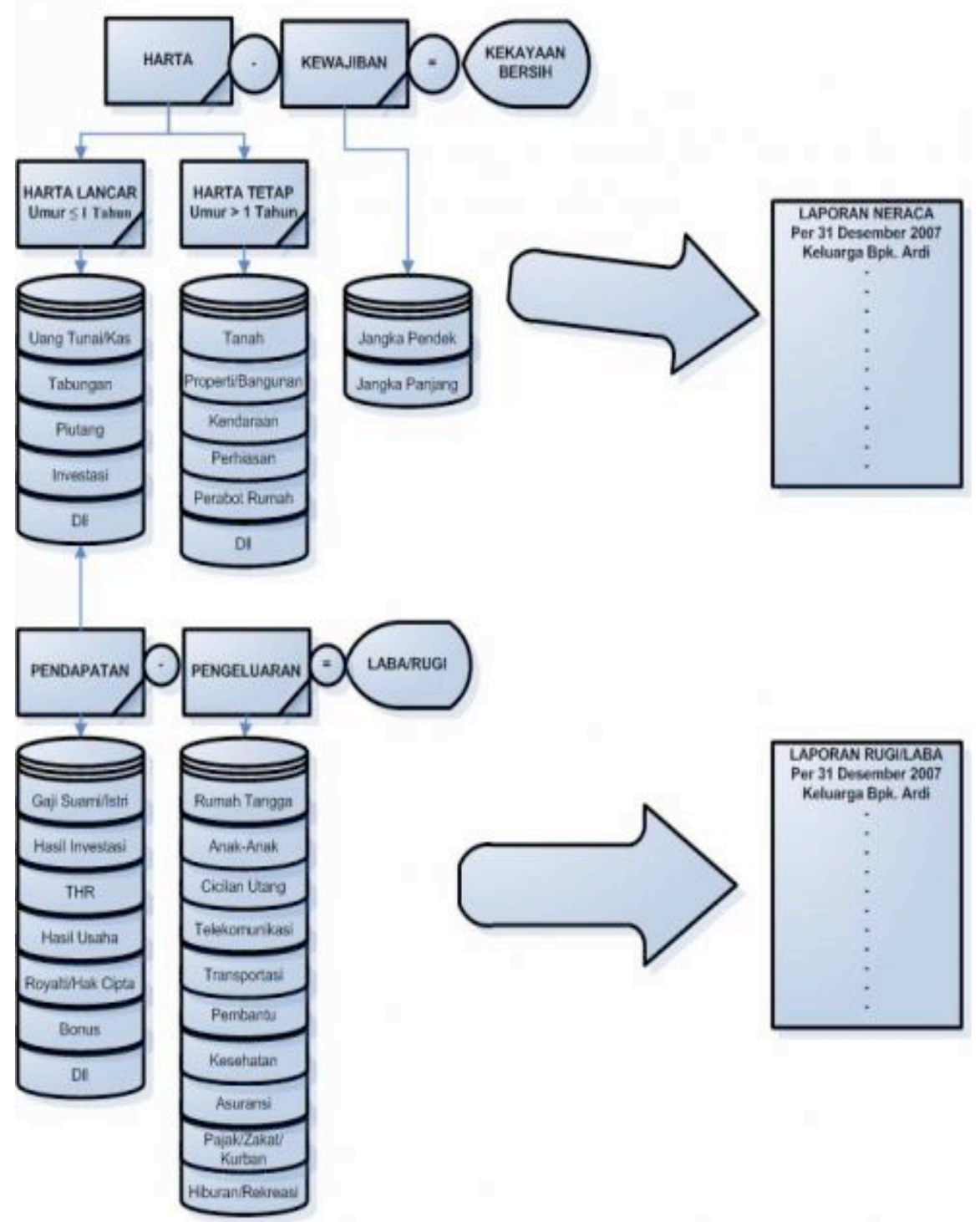

Sumber: My Family Accounting 9

Catatan atas Laporan Kekayaan adalah sebuah laporan yang menyajikan posisi atau kondisi daftar harta dan utang keluarga pada periode tertentu. Tujuan akhir dari laporan ini adalah untuk mengetahui seberapa besar kekayaan keluarga. Apabila dihitung seluruh jumlah harta, setelah ditotal jumlahnya ini dinamakan Kekayaan Kotor. Bila kekayaan kotor tersebut dikurangi seluruh jumlah utang maka dapat diketahui berapa jumlah kekayaan bersih keluarga saat ini.

Laporan Laba Rugi berhubungan erat dengan besarnya pemasukan dikurangi pengeluaran. Ada dua komponen utama dalam penyusunan laba rugi, yaitu jumlah pemasukan dan jumlah pengeluaran dalam satu 
periode/bulan.

Selanjutnya dikurangi jumlah pendapatan dengan pengeluaran, apabila jumlah pendapatan melebih jumlah pengeluaran berarti pada periode/bulan tersebut keluarga mendapatkan laba, tetapi apabila jumlah pengeluaran lebih besar dari jumlah pemasukan berarti keluarga mengalami kerugian.

Setelah membuat laporan kekayaan dan laba rugi, apabila diterapkan dengan disiplin setiap bulan, kemudian disimpan laporan atau catatan tersebut, maka dapat dilakukan analisis dan perbandingan berapa persen pertumbuhan atau penurunan kekayaan dan laba atau rugi keluarga dibanding tahun-tahun sebelumnya. Sehingga sebagai manajer keuangan keluarga dapat mengambil beberapa keputusan yang berkaitan dengan peningkatan kondisi finansial keluarga.

\section{Kiat Sukses Dalam Mengatur Keuangan Keluarga}

Menurut Ahmad Gozali (2009) ${ }^{10}$ kiat dan tips rahasia sukses dalam mengatur keuangan keluarganya dapat ditempuh dengan langkahlangkah sebagai berikut, yaitu:

Pertama, Setiap kali menerima gaji maka langkah awal yang terpenting yang harus dilakukan pertama kali adalah dengan membayar cicilan hutang terlebih dahulu. Karena hutang adalah kewajiban terpenting yang wajib dipenuhi kepada pihak lain apakah dari bank dan institusi finansial lainnya. Kedisiplinan membayar cicilan merupakan cerminan rapor dan nama baik keluarga. Menjaga nama baik sebagai seorang debitor sangat penting, karena akan bermanfaat nantinya di masa yang akan datang. Selain itu pula dengan memprioritaskan membayar cicilan ini, berarti sudah menghargai para kreditor yang sudah berbaik hati meminjamkan uang kepada keluarga.

Kedua. Setelah membayar cicilan hutang, selanjutnya yang dilakukan adalah berzakat atau memberikan sumbangan keagamaan, sebagai salah satu bukti rasa syukur kita kepada Allah SWT. Dia-lah yang telah memberikan karunia rezeki kepada kita semua, sehingga kita bisa melakukan aktivitas ekonomi keseharian dengan lancar tanpa kekurangan. Sehingga Allah SWT akan semakin menambah karunia dan rezeki yang berlimpah kepada kita.

Ketiga, yang tidak kalah penting adalah menyisihkan minimal 10\% penghasilan untuk ditabung/investasi. Karena, salah satu kebiasaan buruk adalah menunggu kalau ada sisa uang di akhir bulan, padahal kenyataannya hampir selalu tidak ada yang tersisa, itu berarti tidak pernah akan bisa menabung.

Keempat. Langkah terakhir adalah menghabiskan uang gaji atau penghasilan yang tersisa. Baik untuk memenuhi berbagai keperluan rutin keluarga seperti belanja isi dapur, makan, lauk-pauk, asuransi, sekolah anak, rekreasi, beli baju dan sebagainya. 
Dengan mengikuti langkah dari 1-4 di atas diharapkan semua dapat meraih kesuksesan dalam mengatur keuangan keluarga tanpa pusing dan stress, apalagi sekarang sudah ada tools berupa software My Family Accounting dapat mempermudah dalam pelaksanaannya pengelolaan keuangan.

Kemudian disamping kiat di atas ada beberapa hal yang perlu dilakukan dalam keluarga, yaitu: a) Buat perencanaan, baik perencanaan jangka pendek atau perencanaan jangka panjang. Rencana jangka pendek berkaitan dengan kebutuhan saat ini, antara lain biaya hidup sehari-hari hingga keperluan sekolah anak-anak. Rencana jangka panjang dapat diwujudkan dalam bentuk tabungan ataupun aset produktif. b) Berbagi tugas dengan pasangan. Setiap persoalan yang timbul dari pembagian tugas perlu dibicarakan secara jelas dan saling terbuka. Tidak boleh ada rasa saling curiga dan hendaknya bisa diselesaikan bersama-sama. c) Siasati Pengeluaran Ekstra. Pengeluaran perlu diatur sedemikian rupa, dan tetap tidak boleh mengurangi keperluan rumah tangga setiap bulannya ${ }^{11}$

Rumah tangga memiliki gaya dan pola yang tidak sama dalam hal pengaturan dan sistem pengeluaran keuangan. Tetapi, setidaknya dengan perencanaan ini akan semakin mudah menata manajemen keuangan rumah tangga. Ini akan bermanfaat untuk masa sekarang dan masa datang.

Untuk itu perlu suatu cara yang dapat mengelola keuangan keluarga yang baik. Karena uang seringkali menjadi penyebab terjadinya perceraian. Perselisihan mengenai keuangan bisa saja terjadi disaat uang melimpah maupun disaat kekurangan uang. Masyarakat Indonesia merasa risih bila harus membicarakan masalah keuangan dalam keluarga. Oleh karena itu perlu semua kalangan masyarakat terutama pasangan suami istri untuk belajar saling terbuka mengenai keuangannya masingmasing. Setiap orang memiliki pandangan mengenai uang yang berbedabeda karena suami atau istri dibesarkan di lingkungan yang berbeda. Kegagalan dalam membicarakan soal uang di dalam keluarga berpotensi menimbulkan permasalahan.

Menurut Muhamad Ichsan ${ }^{12}$ ada tiga tipe pengelolaan yang bisa dipilih sesuai dengan keinginan keluarga.

Pertama, Uang bersama dan Sistem Amplop.

Penghasilan suami istri langsung digabung bersama. Setelah itu, gabungan kedua pendapatan langsung dialokasikan ke pos-pos pengeluaran rutin yang telah dihitung lebih dulu. Sebaiknya, setiap pos diwakili oleh satu amplop. Pos-pos pengeluaran itu pada beberapa keluarga, bukan saja kebutuhan rumah tangga makan minum, dan listrik saja, tapi juga termasuk membayar kredit rumah, cicilan mobil, listrik, telepon, uang sekolah anak, asuransi dan kebutuhan mobil (bensin, servis berkala, kerusakan, dan lain-lain). Bahkan tabungan, pengeluaran pribadi 
ayah-ibu dan liburan pun jadi amplop tersendiri. Bila ada sisa, dimasukkan ke dalam tabungan suami atau istri, atau khusus membuka lagi account bersama di bank untuk menampung sisa amplop setiap bulannya.

Kedua, Membagi Berdasar Persentase

Bentuk manajemen ini adalah membagi tanggung jawab dalam bentuk jumlah atau persentase seluruh kebutuhan keluarga, setiap bulan dihitung termasuk pos darurat dan pos tabungan. Masing-masing sepakat menyumbang sebesar jumlah tertentu untuk menutupi kebutuhan tersebut. Sisanya digunakan sebagai tabungan pribadi untuk kebutuhan pribadi.

Ketiga, Membagi Tanggung Jawab

Misalnya, suami mengeluarkan biaya untuk urusan "berat", seperti membayar kredit rumah, cicilan mobil, listrik, telepon, uang sekolah anak, kebutuhan mobil, dan asuransi. Sementara bagian istri adalah belanja logistik bulanan, pernak pernik rumah, jajan, dan liburan akhir pekan dan pos tabungan. Dilihat dari jumlahnya, suami menanggung lebih banyak dana. Tapi istri juga punya peranan dalam kontribusi dana rumah tangga. Kalau ternyata istri yang memiliki pendapatan lebih besar, tentunya hal ini juga bisa dilakukan sebaliknya.

Hal di atas sangat dipengaruhi oleh kebiasaan dan kesepakatan antara suami dan istri. Apabila semua dapat didiskusikan, maka persoalan keuangan keluarga bukan lagi menjadi masalah dalam keluarga. Hal terpenting adalah saling keterbukaan serta menjalani kehidupan keluarga dengan tanggung jawab bersama.

\section{SIMPULAN}

Kesinambungan kehidupan keluarga menuju keharmonisan menjadi suatu keniscayaan bagi terwujudnya keluarga sakinah. Di antara faktor penting yang menjadi penunjang adalah pemahaman keluarga terhadap manajemen keuangan yang tepat. Masih cukup banyak kondisi keluarga yang rentan gejolak yang diakibatkan ekonomi rumah tangga.

Dengan adanya pemahaman yang baik tentang laporan keuangan keluarga, didukung oleh perencanaan yang baik, pembagian tugas dengan pasangan dan usaha mensiasati pengeluaran ekstra maka rumah tangga dapat melalui masalah-masalah keuangan keluarga dengan solusi yang benar. Hal terpenting adalah saling keterbukaan serta menjalani kehidupan keluarga dengan tanggung jawab bersama

\section{Endnotes:}

1 Lisma Dyawati Fuaida (2004)http://www.digilib.ui.ac.id

2 http://id.wikipedia.org/wiki/Manajemen 
3 M.Manullang (1983), Dasar-dasar manajemen, Ghalia Indonesia, Jakarta, hal 15-16

4 Sutisna, 2009, http://sutisna.com/artikel/ilmu-sosial/manajemen/penger tianmanajemen-3/

$5 \quad$ Ibid

6 http://penuhide.blogspot.com/2009/09/manajemen-keuangan.html.

7 http://myfamilyaccounting.wordpress.com/2010/05/19/rahasia-sukses-mengaturkeuangan-keluarga/

$8 \quad$ Ibid

9 Ibid

10 Ahmad Gozali (2010) http://myfamilyaccounting.wordpress.com/ 2010/05/19/rahasia-sukses-mengatur-keuangan-keluarga/

11 http://www.astaga.com/content/3-trik-sukses-mengelola-keuangan-keluarga

11 http://penuhide.blogspot.com/2009/09/manajemen-keuangan.html.

11http:/ / myfamilyaccounting.wordpress.com/2010/05/19/rahasia-suksesmengatur-keuangan-keluarga/

12 Muhamad Ichsan, 2010, http://blog.keuanganpribadi.com/mengelola-keuangankeluarga/

\section{DAFTAR PUSTAKA}

Ahmad Gozali. 2010. http://myfamilyaccounting.wordpress.com/ 2010/05/19/rahasia-sukses-mengatur-keuangan-keluarga/

http://id.wikipedia.org/wiki/Manajemen

http://myfamilyaccounting.wordpress.com/2010/05/19/rahasia-suksesmengatur-keuangan-keluarga/

http://myfamilyaccounting.wordpress.com/2010/05/19/rahasia-suksesmengatur-keuangan-keluarga/

http://penuhide.blogspot.com/2009/09/manajemen-keuangan. html.

http://penuhide.blogspot.com/2009/09/manajemen-keuangan. html.

http://www.astaga.com/content/3-trik-sukses-mengelola-keuang ankeluarga

Lisma Dyawati Fuaida. 2004. http:/ / www.digilib.ui.ac.id

M.Manullang. 1983. Dasar-dasar Manajemen. Jakarta: Ghalia Indonesia

Muhamad Ichsan, 2010, http://blog.keuanganpribadi. com/mengelolakeuangan-keluarga/

Sutisna. $2009 . \quad$ http://sutisna.com/artikel/ilmu-sosial/ manajemen/pengertian-manajemen-3/ 
